\title{
Global Humanism: Possibilities and Risks of a New Humanistic Model
}

- Lisz Hirn

"Between right and wrong is a place, where we will meet." (Rumi)

\section{Introduction}

The world develops terrifically fast: Technologies, media, states... But do humans develop as fast as their inventions? Which effects does the globalization have on the understanding of the individual and humanity? We have to choose between lots of possibilities - thanks to technology and research, but: What should we do now? How should we handle the potential which is available for us? My book „Global Humanism possibilities and risks of a new humanistic model" appeared in 2010 and discusses the possibilities and risks of a new, ethical model, a Global Humanism, which puts the individual as a global being in the centre of attention.

Humanism is a big idea which everyday life puts to the test. I have recently returned from travels all around the world and to keep your humanistic attitude while travelling is a special challenge. It also showed me the necessity of a global ethical concept, which can apply in a lot of human environments. Nevertheless, the important question to be discussed remains: What can an ethical model like the Global Humanism really perfom? This question caught my interest as a scholar.

\section{What does global humanism mean?}

Global Humanism attempts the construction of a holistic, ethical draught which has the potential to find worldwide validity and recognition, also in terms of adaptation. Although holistically designed, Global Humanism is not a closed ethical system, but a humanistic movement based on the interaction of 
individual and collective ethics. A global humanism has become necessary by the developments of technology, science, society and economy which are transported through media and mass communication. A global humanism serves to allow an intercultural and interpersonal teamwork which takes note of the respective cultural differences and does not try to annihilate such differences.

The model of Global Humanism can be understood as a modus vivendi which aims at a tolerable "living together" - for the individual and the collective. Material values were in the foreground of many actual concepts; the moral values and aims were derived from these material values. In the critical draught of the Global Humanism, the development of immaterial values is in the foreground, like that of a critical consciousness, and the material values are used for the support of the immaterial ones. The following answer to the question is central: Is the holistic model of this Global Humanism more adequate to solve and innovate global human interactions and if yes, why?

\section{What is the concept?}

One of the ideas which is into the concept of the Global Humanism is the idea of an human condition. What does one understand by "human condition"? It can be basically translated with "human basic condition", i.e. it is about the existential limits of the individual, the conditions of his existence, of birth, of suffering and of death. A specific culture doesn't turn you into the person you are. To develop culture, it needs plurality it needs more than one person. Gender and age aren't sufficient to create identity, however are an expression of a specific individual. From this basic human condition, we can derive basic values or the "basic equalization", which the Global Humanism emphasizes. All human beings are exposed to the same human condition. Consequently, the human condition is a universally valid principle.

The mutual goodwill and the mutual esteem originate from the knowledge of the characteristics which all human beings have 
in common, in doing so the human condition also includes the human claim for fulfilment of primary and for the possible fulfilment of secondary etc. needs. This general respect of human needs is often subsumed under the concept of human dignity which is not less problematic. Most of the intercultural difficulties originate from this conceptual lack of clarity concerning different images of human dignity, fundamentalist convictions, certain aspects of globalization and above all conflicting power interests. And further: Besides, the variability of the concepts brought into the play of human dignity can be illustrated by two positions: The view that (1) the right to be respected for one's own dignity is not entitled to every person, that is automatically, but first obtained by certain achievements which also can get lost again or may be limited. The other view states that (2) respect is granted to everyone and must be absolutely respected at all times.

\section{Conclusion}

It is remarkable that both positions interlock. What has to be achieved is respect for everyone's human condition, thereby confirming the claim of one own's dignity. Furthermore, it is important to stimulate the consciousness that dignity comes up to everybody. A task which has to be undertaken by such disciplines as Media and Communication Sciences, Philosophy, Sociology, Cultural and Social Anthropology.

People always interact in social networks, so logically their needs are necessarily tied together and are rarely independent. Thus seen, the dignity of a convicted murderer is strongly limited (in various countries even annihilated by homicide), following the murderer's example, who has annihilated another one's dignity on account of his action: he has positioned himself beyond the human condition, because he has consciously intervened in it. If the dignity of one person is to be respected, so is the dignity of every person: all human beings have the same human condition. The general validity of human dignity is derived from this conclusion. The untouchability of 
human dignity is derived from the consciousness of one's own dignity, one's own needs and own limitation. Without raising awareness, neither untouchability nor general validity will be achieved. A globalized world gives us the possibility, to broaden our horizons and our options, but also to destruct human dignity and life, annihilate all values and solidarity. If nothing matters, there is nothing to save. Does anything still matter? This model of Global Humanism shows, there could be something...

\section{References}

Barnard, Alan. (2000). History and Theory in Anthropology.

Cambride, UK: Cambridge University Press.

Grabner-Haider, Anton [Hrsg.]. (2006). Philosophie der

Weltkulturen. Die Weltdeutungen und die Theorien der

Wahrheit. Wiesbaden: Marix.

Hörisch, Jochen. (2004). Eine Geschichte der Medien. Vom

Urknall zum Internet. Frankfurt/Main: Suhrkamp.

Hirn, Lisz. (2010). Global humanism. Möglichkeiten und

Risiken eines neuen Humanismusmodells. Wien:

Verlagshaus Hernals.

Monaghan, Leila [Hrsg.]. (2012). A cultural approach to interpersonal communication: Essential readings.

Chichester: Blackwell publishing.

Moser, Franz. (1989). Bewußtsein in Raum und Zeit. Die

Grundlagen einer holistischen Weltauffassung auf wissenschaftlicher Basis. Graz: Leykam.

Paul, Gregor. (2008). Einführung in die Interkulturelle Philosophie. Darmstadt: WBG.

Dr. Lisz Hirn teaches philosophy and arts in Vienna, Austria. Contact: lisz.hirn@gmx.at 